\title{
Exploring the public perception of Communist Heritage in Post- communist Albania
}

\author{
Francesco Iacono ${ }^{1}$ and Klejd L. Këlliçici \\ ${ }^{1}$ McDonald Institute for Archaeological Research, University of Cambridge, ${ }^{2}$ University of Tirana
}

\begin{abstract}
More than a quarter of a century after the fall of the eastern bloc (broadly intended), former communist countries have dramatically changed. Yet the memory of the recent past is sometimes perceived as being accompanied by a considerable sense of unease. This process is mirrored clearly in the way some countries have dealt with the physical remains of the regime. This paper will focus on a case study from contemporary Albania and represents one of the first attempts at addressing the social significance of the remnants of the recent communist past in this country. It is undertaken not only through a theoretical and historical investigation, but also via a direct survey of the public (in this case a sample of citizens of the capital city Tirana). Our results suggest that, contrary to our initial assumptions, there is a considerable widely shared interest in the material remnants of the regime and that its cultural heritage its cultural heritage still needs to be explained.
\end{abstract}

Keywords: Albania, Tirana, Cultural Heritage, Dictatorship, Communist Heritage

\section{Framing the problem}

More than a quarter of a century has passed since the fall of the Berlin Wall and the opening of Eastern Europe. All of the former eastern bloc countries have followed the path of liberalisation and regime change. In the face of these changes, new identity perspectives were opened both internally and externally. While externally it was implied that almost all Eastern Europe countries would be able to join the international structures of the west (i.e. NATO or European Union), internally identity involved coping with the communist past and its vision of the future. The external dimension was relatively easy to deal with, in the short-term; the internal debate on identity however, was far more intense. Both dimensions nonetheless implied the idea of identity building or rediscovering. All former communist countries in Central and Eastern Europe have tried to build a sense of national memory, saving certain aspects of it and often neglecting others, normally the most recent ones.

Defining what was to be remembered and what was to be left to oblivion is, just like defining a national identity, the product of a complex convergence of socio-political, economic and cultural factors. While the nationalist aspects embedded in urban architecture (in features like memorials, monuments celebrating historical figures and so on) were more easily incorporated in the new urban narratives of the post-communist state, this was not the case for features more deeply imbued with the ideology of dictatorship. The end of the Cold War put a question mark over the survival not only of communist buildings, but also of the very idea of the city that had emerged as a result of the process of social engineering promoted by the regimes (Bater 1980). 


\section{Communist heritage}

Similar complex processes of negotiation and related tensions are not unique to former eastern bloc countries. Heritage scholars have long recognised the ubiquity of such conflict situations, suggesting concepts like difficult, dissonant and unwanted heritage (Tunbridge \& Ashworth 1996; Henderson 2007; Macdonald 2008). Heritage of this kind has been identified in a variety of environments (Logan \& Reeves 2009). Probably the best-known case in Europe is represented by the monumental heritage from the National Socialist period in Germany, epitomised by the Rally Grounds in Nuremberg, Germany. In this case, the seminal work of Macdonald (2006; 2008) has extensively highlighted the complex lattice of negotiations involved in incorporating the Rally Grounds in the monumental heritage of the city of Nuremberg. Franco's Spain has been a context particularly well studied through a variety of approaches which incorporate both ethnography (Viejo-Rose 2014) and archaeological methodologies (González Ruibal 2009). Other examples, dealing specifically with the heritage of dictatorship of former eastern block countries, have also been explored (Light 2000a; 2000b; Otto 2008; Ivanov 2009), although the perspective employed in those studies has frequently been that of tourism specialists. Sometimes doubts about the very need to commemorate a past so near in time have also been advanced, particularly in the context of countries where there is a need for prioritising resources to be spent on heritage (Harrison 2013).

It needs to be considered however, that for countries where dictatorship has existed, this had represented a unique experience which has left an indelible historical mark whose memory should not be left to oblivion. Its importance goes beyond local interests and this is highlighted by the fact that attention and curiosity towards the material remains of the regime have also been shared by a conspicuous number of international tourists who visit many former eastern block countries every year, demonstrating an explicit interest in the recent communist past.

Beyond their materialisation in concrete buildings, memorials and similar structures, the fil ronge of all definitions of difficult heritage is the presence of a painful experience which lies at the base of the object/s to be memorialised. However, pain is definitely not enough, even if it is an important common denominator. As Andreas Huyssen remarked (2003: 8)

"to collapse memory into trauma, I think, would unduly confine our understanding of memory, marking it too exclusively in terms of pain, suffering, and loss".

Historical buildings, even recent ones such as those here discussed, are receptacles of fragments of personal and social memories (Connerton 1989) whose pigeonholing into an all-encompassing category of traumatic memory is problematic. It is precisely this element, everyday life, which has often been eclipsed and sacrificed in the official memorialisation of the dictatorial past, in favour of narratives emphasizing the hard conditions of the regime (which undoubtedly existed), the difference with the present, and the difficulties entailed by the transition to democracy (e.g. Maltezi 2012; Sadiku 2011). Our claim is that, although well intentioned, these attempts have reproduced in the new democracies, a bi-dimensional representation of life under the regime that is merely a mirror image of the propaganda machinery of the dictatorship that preceded 
them. In our view, memory, and hence the cultural heritage of dictatorship, needs to offer a well-rounded account of the way the past acts upon the present, distancing itself from immediate political agendas, but not negating the politically laden nature of heritage. It is imperative to take into account all the stakeholders involved, whilst at the same time avoiding both chauvinistic nostalgia and moral anathemas. This is particularly problematic in contexts such as former eastern bloc countries, where the temptation of deploying memory (particularly of recent events) as a tool for political struggle is very high (Stan 2006; Friszke 2009). In order to do this, it is undoubtedly necessary to keep well in mind the various political goals of actors involved, and in addition to integrate as much as possible the voice of the public through tools that minimize the influence of consolidated structures of power (i.e. political parties). There are several possible strategies for doing this, but the one that we have chosen to adopt here entails the use of a survey. The specific context in which we employ this strategy is modern day Albania. Before discussing our results, however, it will be necessary to briefly introduce the specificities of our case study.

\section{The Albanian case study: Tirana and the Pyramid a (very) brief historical in- troduction}

As in other former eastern bloc countries, in the immediate aftermath of Albania's transition to democracy, the dictatorship period was simply perceived as a burden that, embracing the new set of values of the western world, had to be deliberately and swiftly forgotten. Recently, however, a new attitude has emerged and the heritage from the dictatorship period has started to attract the interest of scholars, artists and institutions alike, resulting in a number of recent publications, websites and initiatives (Glass 2008; Stefa and Mydyti 2009; Myhrberg 2011; Malltezi 2012; Van Gerven Oei 2015). In other words the past is creeping back in.

In this article, our attention will be focused in particular on one of the most iconic monuments from the communist period present in the capital city Tirana: the former personal museum of the dictator, broadly known to Albanians as Piramida (the Pyramid). A qualitative analysis based on interviews with a limited number of archaeologists and heritage professionals realised by Myhrberg (2011) provided an excellent foundation for the present study although our aim is completely different as our perspective here is chiefly quantitative/ demographic. In this paper our efforts will be directed solely to a preliminary tracing of the main quantifiable and recognizable trends in the data.

In the period between 1945 and 1991 Albania was the locus of a particularly harsh Stalin-inspired regime headed by Enver Hoxha. The particular geopolitical position of Albania, at the interface with the western world, together with a paranoid attitude developed by the dictator over the decades, gradually led the country to absolute isolation and to the interruption of diplomatic relationships within the communist bloc, first with neighbouring Yugoslavia, then with Russia and finally, in the 1970s also with China (O’Donnell 1999: 37-96; Gjeçovi 2009; Milo 2013). Isolation was paired with the establishment of an efficient propaganda machinery as well as by the control of virtually every aspect of personal and social life and the (often violent) coercion of any dissent, real or perceived (Vickers 1999: 189-91). 


\section{The Pyramid as an Hoxhan commemoration}

Despite being obsessed by himself and the perception his people had of him, while alive, Hoxha had an extremely iconoclastic attitude, and avoided the propagation of his image through monuments (in line with a certain attention to avoiding the cult of personality of living people, which was also demonstrated in other communist regimes; see Apor et al. 2004). Indeed, there are virtually no representations of Hoxha dating before 1985, that is the year of his death. With his death and the change of leadership within the P.P.Sh. (Partia e Punes e Shqipërisë, Albanian Workers Party) however, this situation also changed. The new leadership, led by Ramiz Alia, eager for legitimisation, embarked on an ambitious campaign of monumentalisation, which involved both the placing of memorials across the landscape and the realisation of a number of grandiose works. Some of the latter directly represented the dead leader (as in the case of the gigantic statue once located on top of a hill in Gijrokastër, now destroyed and occupied by a hotel), others just evoked his presence.

Within this general climate, an ambitious plan was implemented in the capital city, Tirana, with the aim of filling in the empty spaces left along the main boulevard by the uncompleted half century-old Italian plan. Three empty lots had to serve as the sites for three major modern and ideologically significant buildings for Tirana, namely the Museum 'Enver Hoxha' (Pyramid), the Palace of Congresses and the new Central Committee Building (the construction of this last building had just started when the regime collapsed; Bleta 2010: 77-101). Together with the statue of Hoxha in Skanderbeg Square, the pyramid shaped personal museum of Enver Hoxha was the most tangible attempt to celebrate the former dictator (Figure 1).

The Pyramid was planned in the immediate aftermath of the death of the leader in 1985 and was built over the following three years, being inaugurated on the eightieth anniversarv of the birth of Hoxha in a large celebration. It was a titanic effort involv-

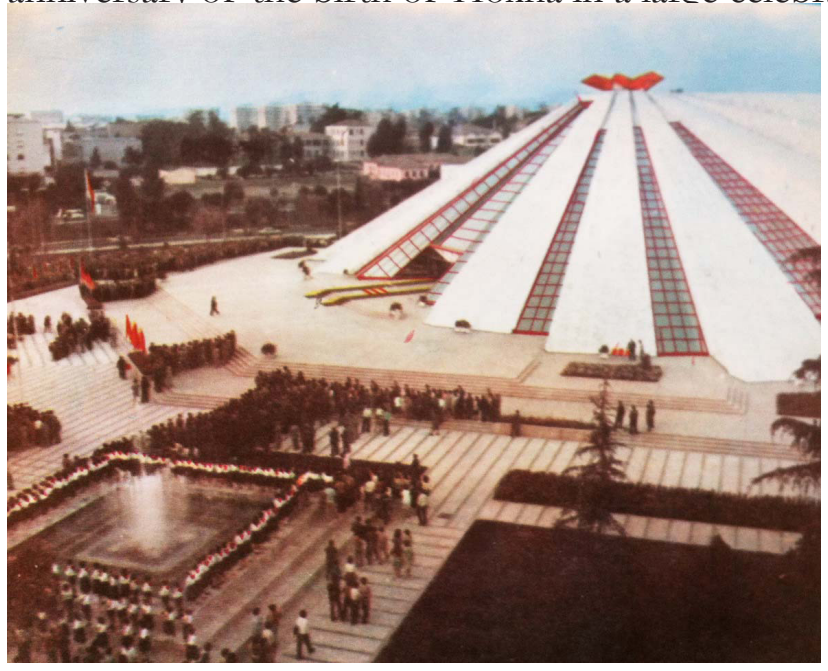

Figure 1. The Pyramid (Piramida) former museum of Enver Hoxha during its inauguration (after Ylli November 1988: 6). ing the 'voluntary' work of a variety of people encompassing workers, architects (led by the nephew of the dictator), historians, museum specialists, artists, decorators and so on (Adhami 2001: 189-90). Much of the construction material was collected and put together from the most disparate areas of Albania, and documents at the Albanian National Archive describe in detail the whole process of procurement. ${ }^{1}$ The amount of resources dedicated to this work

\footnotetext{
${ }^{1}$ General Directory of Albanian Archives, Collection of the Council of Ministries, F.490 V.1986 D.715.
} 
appear even more striking when one considers that the Albanian population was at that time facing one of the most dramatic economic crises in its post-war history (Gjeçovi 2009: 351-8).

Architecturally the Piramida was unique and there are no parallels with other buildings realised in other former eastern bloc countries. Structurally, it was a gigantic octagonal concrete umbrella with straight, gently sloping walls covered in marble interrupted by long longitudinal windows stretching over much of the overall height of the building. Inside, the Piramida was lavish unlike any other building constructed in Albania since the 1950s, when the regime also had been able to count on help from Russia. The museum revolved around a giant hall surmounted by the most significant communist symbol, a star. The same feature was used (in red plastic material) to surmount the outer extremity of the building. Inside it contained the focal point of the museum, a marble statue of a seated Hoxha in the centre of a round hall. The museum had neither a proper entrance, nor a ticket counter, and the hall opened immediately in front of the visitor with Hoxha's statue in the centre. The display of the artefacts and visual materials ran around the circumference of the hall. The museum differed in many respects from traditional museums as the wide-open space of the central hall, allowed no interruption of the narrative of the materials exposed.

\section{The Pyramid in the aftermath of the regime}

After 1991, while almost all public buildings had been definitively adapted to new functions in the new regime, the Pyramid remained probably the only public structure of the communist period in the capital that did not have a clear future. This undoubtedly suggests a general unease, at least on the part of the authorities, with the very existence of such a building. This unease persisted well into the following decade, and even the City Plan of 2003 did not consider the building among those to be re-qualified (Architecture Studio 2003: 13). This is because its peculiar shape and plan had become a standing symbol of communism, difficult to adapt to the new democratic regime. The Pyramid was in fact 'desacralized' as early as mid 1991. The demolition of the grandiose monument of Hoxha marked a change of destination for the building. The very first event hosted was the first trade fair ever held in post-communist Albania and, since then, the Pyramid has been used for the most diverse purposes. Among these were concerts and other kinds of non-official activities held under the name of the International Cultural Centre. To further emphasize the distance of the 'new' Piramida from the regime, in 2006 the right-wing government decided to nominate the International Cultural Centre after the iconic figure of Albanian anti-communism and gulag survivor, Pjetër Arbnori (Elsie 2010: 19-20). Although the Piramida was never to be used as a government building, this does not mean that the state was disinterested in the structure and, actually, a number of extremely costly plans for its restoration and re-functionalisation have been implemented by successive governments since 2004 (such as turning it into the National Theater or the New National Library) but none of them has ever been completed (Resuli 2010). 
At the same time part of the building was adapted to host the offices of one of the main governmental agencies of the new hegemonic power, USAID. In the same period another area of the building started to host the studios of some of the most important private television networks in the country (Top Channel, Alba TV). So while government and the state apparatus of post-communist Albania distanced themselves from the Pyramida, through their connections with foreign organisations and the media, the building acquired a renewed role. For many years, this role probably allowed the building to resist the processes of gentrification and/or more broadly radical development which resulted in the construction of a number of multi-storey buildings in the city centre (Herzfeld 2010; Pojani 2015: 83-4). It is important to consider how this new, albeit shifting, role has actually been much more enduring than the original one envisaged for the building (i.e. as a museum celebrating the dead leader and founder of People's Republic of Albania). Chatting informally with citizens from the capital it is apparent how little impact the original role of the Pyramid has left on public perception of the monument. For the Tiranas (citizens of Tirana), the Pyramid is only one of the most prominent landmarks, amongst many reference points, that help to orientate them through the haphazard web of streets and alleys produced by recent development (Pojani 2010). Indeed, Albanians tend to use buildings and objects, rather than street names, as a point of reference. Visibility is undoubtedly one of the characterizing features of the monument and one that has persisted until now. At the time of its construction the pyramid was designed to be one of the most visible landmarks of the city. Despite a number of skyscrapers and new buildings that have undoubtedly changed the original look of the city, the Pyramid still partly preserves its role as a landmark because it faces the large open space of one of the monumental boulevards. In 2011 the Piramida was at the centre of a quarrel between the leaders of the main parties in Albania: the Democratic Party (Partia Demokratike, right-wing) and the Socialist Party (Partia Socialiste, left-wing). The then Prime Minister and leader of the Democratic Party wanted to demolish the building to make room for a new pharaonic parliament that was to constitute the symbol of the new democratic Albania. Similar attempts are not unparalleled in other former eastern bloc countries where sometimes monuments and public spaces have been remodelled or even destroyed in order to conform to a perceived hierarchy of values (see for instance the case of the renovation of Skopje; Mattioli 2014; see also more generally Iacono \& Këlliçi 2015; Young \& Kaczmarek 2008). No assessment of the social relevance of the pyramida for Tironas was made before announcing the destruction plan and the usual rhetoric of the sacrifice for the greater good was, in this case, particularly thin (Herzfeld 2010). The whole operation was generally seen as an appropriation, on the part of politics, of a former public symbol/space, and indeed it did not convince also many people within the majority party. Such a plan was vocally opposed by a group of Albanian intellectuals who promoted a petition against it that gathered some 6,000 signatures (Klosi \& Lame 2011) and this position was also endorsed by the Socialist party, who were then in opposition. As often happens in Albania, the debate rapidly became coloured with political overtones, with positions being potentially influenced by political sympathy/affiliation.

The new government has dismissed demolition plans and has timidly started to use the building for cultural activities like concerts and art-exhibitions. However, so far no 
new overall project for its re-functionalisation has been presented, and it is not clear whether plans approved and partially implemented through the years since 2004, still constitute the blueprint for future interventions. To this extent, the main issue is the condition of the building. The Piramida is in a sorry state as, despite the plan for the new parliament has not been concluded, its dismantling was commenced in 2011 and, as of today, the building stands as an empty concrete shelter (Figure 2). ${ }^{2}$

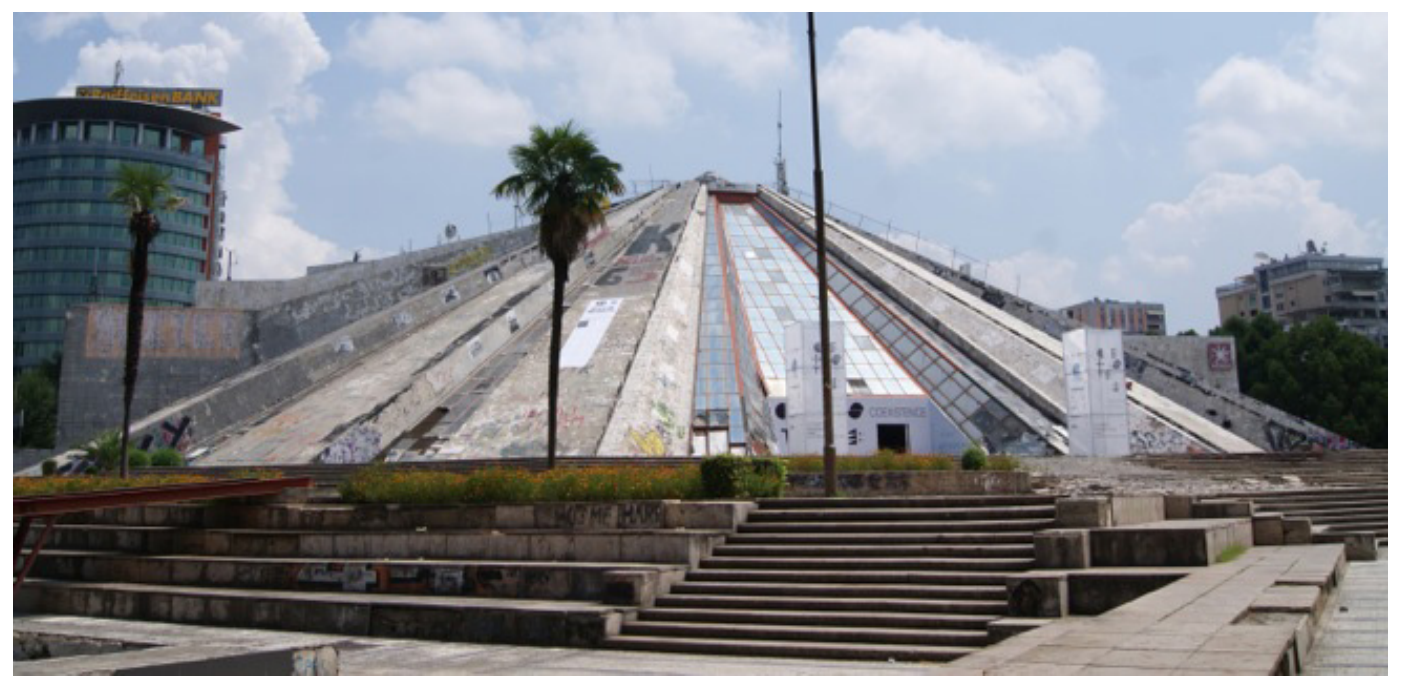

Figure 2. The Piramida in its current state of preservation. Photograph by I. Gramo.

\section{Survey}

As mentioned above, our study aimed to explore the public perception of the Piramida in current Albanian society by the means of a survey (see also Iacono \& Këlliçi 2015). More specifically, we wanted to try to bypass the pervasive influence of political parties, capturing the personal engagement of Albanians with the Piramida and, more broadly, with the tangible heritage of the dictatorship. Given the complex political setting in which our work took place, it is necessary to specify the temporal context of our survey, which might have played a role in its results. The survey occurred between December 2013 and February 2014, some six months after the last political elections that marked a change in government from the Democratic to the Socialist party. It seems possible that the results would have been, to a certain extent, different, perhaps more in line with the position of the party in power at the time, had the survey been undertaken before the elections (although it must be stressed that the plan for the new parliament was criticised also within the Democratic Party).

Directly connected to this aspect is the first of the two main expectations we had at the onset of this investigation. In 2011 the Piramida had been a bone of contention between the two main parties of Albania, and because of the strong division and over-politicisation of opinions within Albanian society, we hypothesised that valueassessments on the material heritage from the communist period were likely to be

\footnotetext{
${ }^{2}$ Very recently the new Mayor, Erjon Veliaj (elected in 2015), initiated some very preliminary intervention on the building.
} 
strongly polarised, following the positions of these two political actors. The second expectation we had was that, because of the peculiar dynamics of socialisation typical of the communist regime, in Albania as well as elsewhere, older generations were more likely to feel more attached to the material remains of the regime, since some had spent vast amounts of time in contact with them.

In order to explore these two hypotheses, we collected a relatively large number of online responses (360 overall), gathered through advertising our survey through various social media outlets. However, since we recognised that a substantial proportion of older respondents could have potentially been put off by the use of electronic means, we decided to collect an additional sample through 'traditional' methods (i.e. face-toface interviews) conducted in specific spots of the city frequented by over 60 year olds. The questionnaire is reproduced in the Appendix at the end of this article.

\section{Discussion of results}

The results have largely contradicted our expectations and, additionally, the unambiguity of at least some of the trends noticed, indicates that our caution with respect to the effects of the elections was largely unwarranted.

As far as political divisions are concerned, when we asked about the plan to destroy the Piramida (question no. 13) there was not much difference: the overwhelming majority of respondents strongly disagreed on this. As for generational differentiation, in relation to this specific issue, there were no significant differences with older people (Fig. 3). The reasons given as justifying the need for preserving the Pyramid are the most disparate and no immediately recognizable trends have been identified (question no. 14). It is extremely likely that this apparently homogeneous response was due to the specificities of the monument discussed. Although one of the most recognizable landmarks in the capital city (as quoted in question n. 1, among the five most important monuments in Tirana), the Pyramid is fairly recent, having been completed in 1988. This means that older generations did not spend substantial amounts of extra time in developing a 'special relationship' with the Piramida as previously postulated.

All

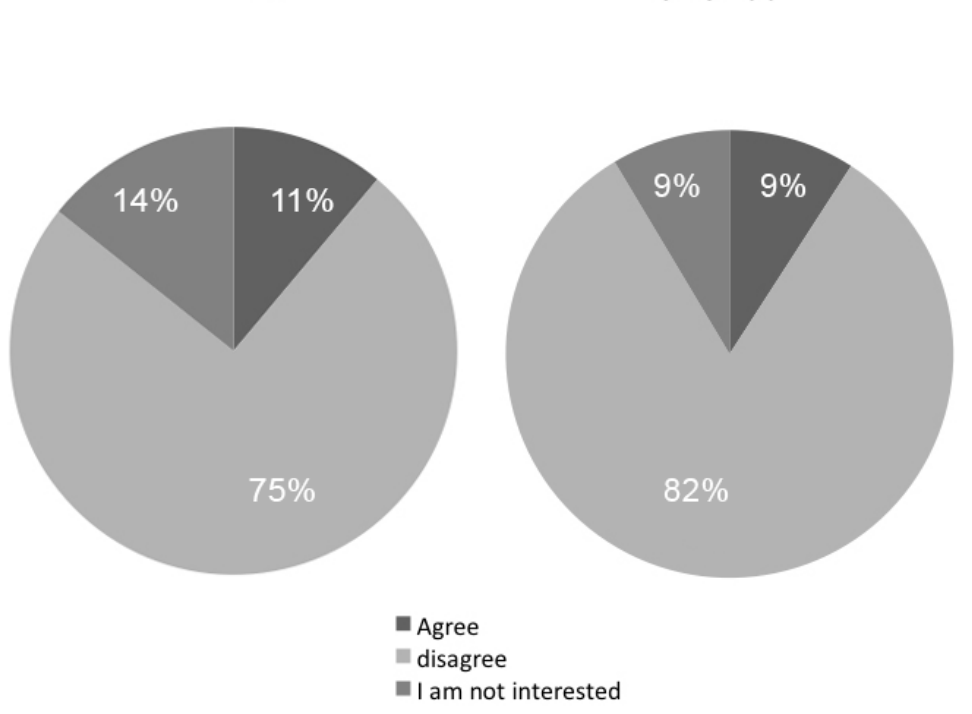

Over 60

Figure 3. Responses to the question: Do you agree or disagree about the plan to demolish the Pyramid? 
This highlights one of the main contradictions embedded in the public perception of this building. While, from an 'external' perspective the building is undoubtedly associated with the communist regime, its use as the museum of Enver Hoxha lasted only four years and its use after the fall of the dictatorship stretched over a much longer period. Such an aspect is mirrored in the fact that the sample overall largely associated the building with Tirana as a city, rather than with either communism or specifically with Enver Hoxha (Fig. 4). Here however generational differences seem to be much more meaningful; in the sub-sample of people over 60, those that associate the Piramida with the dictator is overwhelming (58 percent), while the age group 20 to 59 years old predominantly connects the monument to the city itself (51 percent). In other words, the younger age-group that did not take part in the efforts necessary for the construction of the monument, saw the Piramida predominantly as something that had more or less always been there and hence part of their affective geography, or of

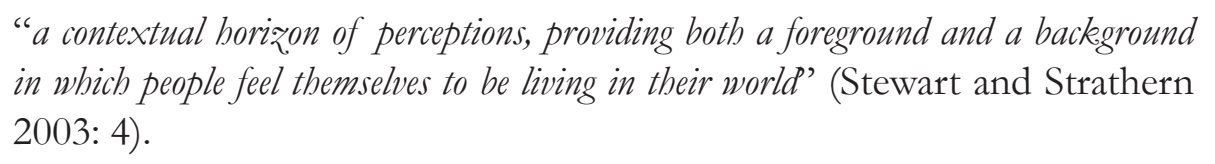

Those over 60 years old, on the other hand, could not avoid taking into account in their value judgments the effort of an entire generation directed at its construction. Even if the involvement was not direct, the process of identification of individuals with their generation was probably enough to stimulate similar answers. The fact that Enver Hoxha is identified as the most important association is not surprising, given the strong personality cult characterising the Albanian regime.

Moving to the broader category of monuments of the communist period, perceptions of citizens of Tirana seem to be more openly influenced by the generational factor previ-

(20-59 уо)

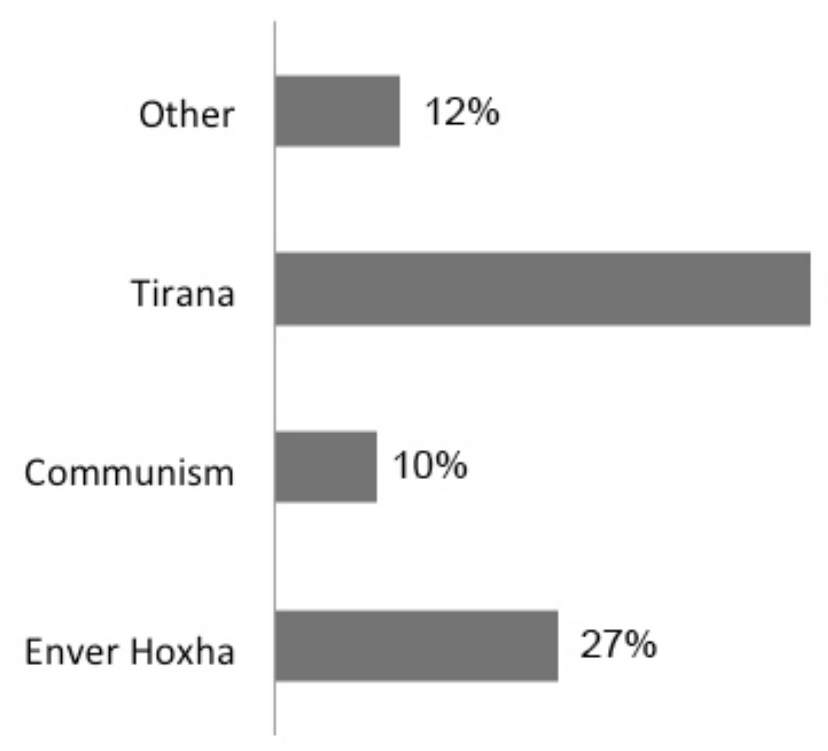

\section{Over 60}

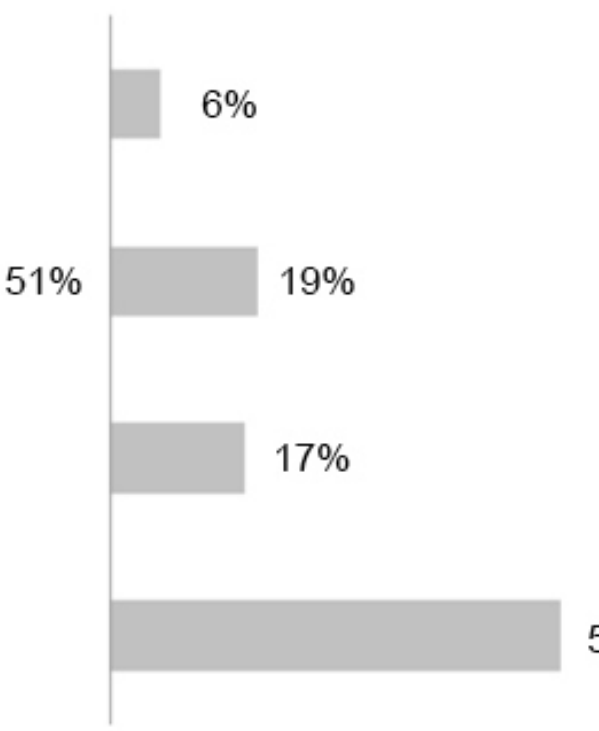

Figure 4. Responses to the question: What does the Pyramid makes you think of? 
ously identified. Predictably, the percentage of people feeling 'very attached', instead of just 'attached', to the material remains of the communism is considerably larger among those over 60 (Fig. 5). We analysed the data for trends relating to the category of monument - institutional buildings, bunkers, statues-lapidaries, prison camps, war memorials - to assess if there was any predilection and/or recognizable pattern, but none could be discerned. Looking at the specific subset of the over 60s, there was a quite clear-cut tendency to attribute more importance to bunkers and prison camps, which are more frequently quoted as the most important category of monuments from the period of the dictatorship. While the case of the prison camps can be easily understood through the categories of painful heritage highlighted by much of the previous scholarship (e.g. Logan \& Reeves 2009), this is not the case with respect to the bunkers. Bunkers (Fig. 8; see Galaty et al. 2000; Glass 2008; Stefa \& Mydyti 2009), probably the most universally known feature of the landscape of the communist period in Albania, were the product of one of the worse periods of the regime. Between 1977 and 1981 Hoxha's paranoia (motivated principally by the possibility of attacks from Tito's Yugoslavia) led to the realisation of some 400,000 concrete bunkers of various shapes and sizes (Glass 2008; Stefa \& Mydity 2009). As remarked by many, beyond the titanic economic effort (quantifiable as about 2 percent of the overall material production of the country), the most enduring effect of the 'bunkerisation' of Albania was the creation of what has been defined as a 'siege mentality' (Glass 2008: 41-42; O’Donnell 1999: 137). The broad Albanian population was kept in the constant fear of foreign invasions, resulting in a diffused militarisation. The consequences of these processes are far-reaching and cannot be discussed here in full. As for the influence on the perception of the built environment, it is necessary to highlight that the construction and maintenance of bunkers were the outcome of the collective effort of army members and civilians alike. In her in-depth examination of the role of bunkers in Albanian rural society, Glass (2008: 31-5) emphasizes the critical role played by families and individuals in both their construction and maintenance, through voluntary work:
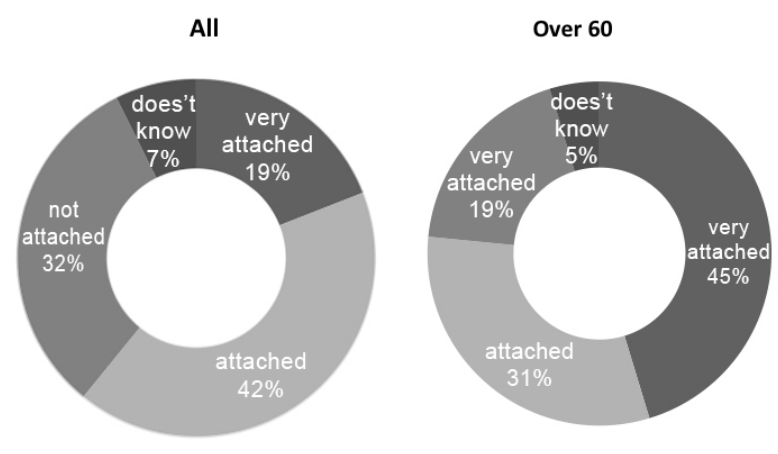

Figure 5. Answer of the sample to the question: Do you feel attached to the monuments of the communist period? "bunkers are personified by people and people are personified by bunkers. Their biographies are intertwined; from the population involvement in their creation to military use under communism and to later re-use phases" (Glass 2008: 44).

This is particularly interesting as it confirms the importance of direct activity, engagement and physical closeness in shaping the relationship between Albanians and the inheritance of the communist period. 
Finally, going back to the broad category of the monumental heritage of the dictatorship, one aspect upon which the consensus among the surveyed sample seemed to be almost unanimous, notwithstanding age categories, was the general necessity to preserve memory of the communist past (over 95 percent of the sample agreed; question no. 2) and of its material remains (83 percent; no. 4) for which resorting to public funding was also considered positively by the majority of the respondents (63 percent; no. 10). Such buildings were most frequently associated with communism (in 37 percent of cases) and with the specific place where they are located (28 percent), while the association with Enver Hoxha appears not to have been particularly frequent (14 percent, question no. 6). Such an interest might appear obvious, but it marks a definite change from the perceived will of other former eastern block countries, which simply condemned their recent past to a total damnatio memoriae. Proof of how recent this change is lies in the very fact that, despite personally having an interest in the cultural heritage of the dictatorship, the vast majority of respondents saw the Albanian public as lacking interest in relation to this topic, with less than a third ( 27 percent) of the sample suggesting a general interest in the material remains of the dictatorship (question no. 8). When asked to explain the reason for a general lack of interest in the tangible heritage of the dictatorship (question no.9), no overwhelming trend emerged although the most frequent answer was that it reminded them of a bad period (occurring in just 21 percent of the cases).

\section{Conclusions}

Together with large-scale changes in social, political and economic relations, the fall of the Berlin Wall resulted also in a massive reconfiguration of the way identities were created over vast areas of Europe (Schwandner-Sievers \& Fischer 2002; Fawn 2003; Kaneva 2014). Within these processes, monumental heritage and, more broadly, the built environment, played an important role that has been recognized but only partially explored by cultural heritage (Huyssen 2003; Bevan 2007; Rampley 2012). In this paper we have claimed that one of the main limitations to our understanding of the relevance of the heritage of the communist period in post-communist countries is simply envisaging it as the memory of the traumatic, the painful and unwanted, a thesis that ultimately rejects the right of many life-histories to be incorporated in public narratives. Of course such a consideration does not mean that traumatic aspects should not be taken into account, nor does it mean that we should embrace a less critical stance towards communist regimes and their crimes through some fifty years of history of the eastern bloc. Rather, memory-representations (either through the discussion of monumental heritage, or other material and immaterial aspects), should incorporate a more well-rounded picture of life under the regime(s) in all its facets, even the nontraumatic ones; this might represent an important step in the process of actually coming to terms with the past.

In this paper we have tried to explore the perception of the monumental heritage of the communist dictatorship period in Albania, a country that, in the period between 1945 and 1991, experienced a particularly harsh regime. We have explored this theme through a survey focused on one of the most symbolic buildings of the communist period in the capital city Tirana, the Piramida, the pyramid shaped personal museum 
of the dictator Enver Hoxha. Our survey yielded rather unexpected results, indicating a widespread affection not only for the Pyramid in particular, but also more generally for buildings realized during the dictatorship.

\section{Acknowledgements}

The authors would like to thank various people who offered critical input for the realisation of this article. Eleni Stefanou, recommended excellent bibliographic suggestions while Marilena Alivizatou commented on an early draft of the questionnaire on which this work is based. Emily Glass kindly allowed us to read her unpublished MA Thesis. Finally, a special thank you goes to Suela Iacono, Fatos Çuçi, Ilir Gramo and all the other friends who shared with us their memory of the late 1980s in Albania. Needless to say the article reflects only the view of the authors and they are solely responsible for any error and/or inaccuracy.

\section{Appendix}

1) Can you list the 5 most important monuments/landmarks of Tirana you can think of?

(open answer).

2) Do you think is useful to preserve the memory of the communist period?

a) yes b) no c) doesn't know.

3) Do you feel attached to the monuments of the communist period?

a) very attached, b) attached, C) not attached, d) doesn't know.

4) Do you think it is useful to preserve the physical remains of the communist past?

a) yes, b) no c) doesn't know.

5) Why do you think the physical remains of the communist period should be protected?

a) because they reminds us all the wrongs made by the regime, b) because they represent part of the history of this country, c) because are part of people's lives d) other..., e) doesn't know.

6) What do monuments of the communist period in general make you think of?

a) Enver Hoxha, b) Communism, c) the specific place in which they are located, d) other...

7) Can you put the following examples of communist buildings in order from the most important to be preserved to the least so?

a) Institutional buildings, b) bunkers, c) statues and other monuments, d) prison camps \& related cemeteries. 
8) Do you think the public in Albania is interested to its communist heritage?

a) yes, b) no, c) doesn't know.

9) If your answer to the previous question was no, why do you think the public is not interested in the heritage of the communist period?

a) it reminds a bad period, b) paying too much attention to that period does not help the process of modernisation of Albania, c) digging too much in the inheritance of the communist period may threaten some people still holding important positions within the Albanian state, d) other...

10) Do you think the Albanian state should devote resources to the preservation of monuments of the communist period?

a) yes, b) no, c) doesn't know.

11) What does the Pyramid makes you think of?

a) Enver Hoxha, b) communism, c) Tirana, d) other...

12) Do you think the pyramid is important as a landscape mark for the city of Tirana?

a) yes, b) no.

13) Do you agree or disagree about the plan to demolish the pyramid?

a) agree, b) disagree, c) doesn’t care.

14) If you disagree, why do you think the pyramid should be preserved?

(open answer).

\section{References}

Adнami, S., 2001. Muzeologiza shqiptare. Tiranë: Shtypur në shtypshkronjën "Gervis". Apor, B., J. C Behrends, P. Jones \& E. A. Rees (eds.), 2004. The Leader Cult in Communist Dictatorship: Stalin and the Eastern Bloc. Basingstoke, Hampshire and New York: Palgrave Macmillan.

ARChitecture STUdio 2003, Rregullore për zbatimin e studimit urbanistik të qendrës së qytetit të Tiranës. Unpublished report: Municipality of Tirana.

BAter, J. H., 1980. The Soviet city: ideal and reality. Edward Arnold London.

Bevan, R., 2007. The Destruction of Memory: Architecture at War. London: Reaktion Books. BLETA, I., 2010. Influences of political regime shifts on the urban scene of a capital city. Case study: Tirana. Unpublished MA Thesis, Middle East Technical University: Ankara.

Connerton, P., 1989. How Societies Remember. Cambridge and New York: Cambridge University Press.

Elsie, R., 2010. Historical Dictionary of Albania. Scarecrow Press.

FAWN, R., 2003. Ideology and national identity in post-communist foreign policies. Journal of Communist Studies and Transition Politics 19: 1-41.

FriszKe, A., 2009. Historical Bias in Poland: Lustration as a Political Instrument, in: H. Swoboda \& J. M. Wiersma (eds.), Politics of the past: the use and abuse of history. Bruxelles: Socialist Group in the European Parliament, 105-12. 
Galaty, M., S. R. Stocker \& C. Watkinson, 2000. Beyond Bunkers: Dominance, Resistance and Change in an Albanian Regional Landscape. Journal of Mediterranean Archaeology 12: 197-214.

GJEÇOVI, XH. (ed.), 2009. Historia e popullit shqiptar: në katër vëllime. 4, Shqiptarët gjatë luftës së dytë botërore dhe pas saj: 1939 - 1990. Tirana: Botimet Toena.

Glass, E. J., 2008. A Very Concrete Legacy: An Investigation into the Materiality and Mentality of Communist Bunkers in Albania. Unpublished MA Thesis, University of Bristol: Bristol.

GonzÁlez Ruibal, A., 2009. Topography of terror or cultural heritage? The monuments of Franco's Spain, in: N. Forbes, R. Page \& G. Pérez (eds.), Europe's Deadly Century: Perspectives on 20th-century Confict Heritage. Swindon: English Heritage, 65-72.

HARRISON, R., 2013. Forgetting to remember, remembering to forget: late modern heritage practices, sustainability and the 'crisis' of accumulation of the past. International Journal of Heritage Studies 19: 579-95.

Henderson, J. C., 2007. Communism, Heritage and Tourism in East Asia. International Journal of Heritage Studies 13: 240-54.

Herzfeld, M., 2010. Engagement, Gentrification, and the Neoliberal Hijacking of History. Current Anthropology 51(S2): 259-67.

Huyssen, A., 2003. Present Pasts: Urban Palimpsests and the Politics of Memory. Stanford, Calif: Stanford University Press.

IAcono, F. \& K. KëLlici, 2015. Of Pyramids and Dictators: Memory, Work and the Significance of Communist Heritage in Post-Socialist Albania. Arqueologia Publica 5: 97-122.

Ivanov, S., 2009. Opportunities for developing communist heritage tourism in Bulgaria. Tourism Review 57: 177-92.

Kaneva, N. (ed.), 2014. Branding Post-Communist Nations: Marketizing National Identities in the "New" Europe. London and New York: Routledge.

Klosi, A. \& A. LAme (eds.), 2011. Piramida e Tiranës: e hijshme, e braktisur, e rrezikuar. Tiranë: Dudaj.

LigHT, D., 2000a. Gazing on communism: Heritage tourism and post-communist identities in Germany, Hungary and Romania. Tourism Geographies 2: 157-76.

Light, D., 2000b. An Unwanted Past: contemporary tourism and the heritage of communism in Romania. International Journal of Heritage Studies 6(2): 145-60.

Logan, W. \& Reeves, K., 2009. Places of Pain and Shame: Dealing with 'Difficult Heritage'. Milton Park, Abingdon, Oxon and New York: Routledge.

Macdonald, S., 2006. Undesirable Heritage: Fascist Material Culture and Historical Consciousness in Nuremberg. International Journal of Heritage Studies, 12(1): 9-28.

Macdonald, S., 2008. Difficult Heritage: Negotiating the Nazi Past in Nuremberg and Beyond. Milton Park, Abingdon, Oxon and New York: Routledge.

Maltezi, L. (ed.), 2012. Terrori Komunisti në Shqipëri. Tiranë: Muzeu Historik Kombëtar. Mattioli, F., 2014. Unchanging boundaries: the reconstruction of Skopje and the politics of heritage. International Journal of Heritage Studies, 20(6): 599-615.

Milo, P., 2013. Politika e jashtme e Shqipërisë. Tiranë: Toena.

Myhrberg, K., 2011. Heritage from the Communist Period in Albania - An unwanted heritage today? Gothenburg: University of Gothenburg.

O’Donnell, J., 1999. A coming of age: Albania under Enver Hoxha. Boulder: New York: East European Monographs; Distributed by Columbia University Press.

Отто, J. E., 2008. Representing Communism: Discourses of Heritage Tourism and Economic Regeneration in Nowa Huta, Poland. Ph.D. dissertation University of Minnesota.

Pojani, D., 2010. Tirana. Cities, 27: 483-95. 
PojAni, D., 2015. Urban design, ideology, and power: use of the central square in Tirana during one century of political transformations. Planning Perspectives 30(1): 67-94. Rampley, M. (ed.), 2012. Heritage, ideology, and identity in Central and Eastern Europe: contested pasts, contested presents. Woodbridge, Suffolk; Rochester, NY: Boydell Press. Resuli, E., 2010. Piramida, inxhinieri: do ta bëjmë teatër. Drejtori: Do ta shembim. Shekulli 29/10/2010: 6-7.

SAdiku, XH., 2011. Genocidi Mbi Kulakët Në Shqipërinë Komuniste: 1948-1990. Tiranë: Geer.

Schwandner-Sievers, S. \& B. J. Fischer (eds.), 2002. Albanian Identities: Myth and History. Bloomington: Indiana University Press.

STAN, L., 2006. The Vanishing Truth? Politics and Memory in Post-Communist Europe. Eastern European Quarterly 40: 383-408.

Stefa, E. \& G. Mydyti, 2009. Concrete Mushrooms: Bunkers in Albania. Milano: Politecnico di Milano.

Stewart, P. J. \& A. Strathern, 2003. Introduction, in: P. J. Stewart \& A. Strathern (eds.), Landscape, memory and history: anthropological perspectives. London: Pluto, 1-15.

Tunbridge, J. E. \& G. J. Ashworth, 1996. Dissonant Heritage: The Management of the Past as a Resource in Conflict. Chichester and New York: Belhaven Press.

Van Gerven Oei, V. (ed.), 2015. Lapidari. New York and Tirana: Punctum Books. Vickers, M., 1999. The Albanians a modern history. London: I.B. Tauris Publishers. Viejo-Rose, D., 2014. Reconstructing Spain: Cultural Heritage and Memory After Civil War. Sussex Academic Press.

Young, C. \& S. Kaczmarek, 2008. The Socialist Past and Postsocialist Urban Identity in Central and Eastern Europe The Case of Lódź, Poland. European Urban and Regional Studies 15(1): 53-70. 
